Prepared for the U.S. Department of Energy

under Contract DE-AC05-76RL01830

\title{
Inventory of U.S.-led International Activities on Building Energy Efficiency
}

\section{Initial Findings}

\section{A Delgado \\ M Evans}

April 2010

\section{Pacific Northwest}

NATIONAL LABORATORY

Proudly Operated by Battelle Since 1965 


\title{
DISCLAIMER
}

This report was prepared as an account of work sponsored by an agency of the United States Government. Neither the United States Government nor any agency thereof, nor Battelle Memorial Institute, nor any of their employees, makes any warranty, express or implied, or assumes any legal liability or responsibility for the accuracy, completeness, or usefulness of any information, apparatus, product, or process disclosed, or represents that its use would not infringe privately owned rights. Reference herein to any specific commercial product, process, or service by trade name, trademark, manufacturer, or otherwise does not necessarily constitute or imply its endorsement, recommendation, or favoring by the United States Government or any agency thereof, or Battelle Memorial Institute. The views and opinions of authors expressed herein do not necessarily state or reflect those of the United States Government or any agency thereof.

\author{
PACIFIC NORTHWEST NATIONAL LABORATORY \\ operated by \\ BATTELLE \\ for the \\ UNITED STATES DEPARTMENT OF ENERGY \\ under Contract DE-AC05-76RL01830
}

Printed in the United States of America
Available to DOE and DOE contractors from the Office of Scientific and Technical Information,
P.O. Box 62, Oak Ridge, TN 37831-0062;
ph: (865) 576-8401
fax: $(865)$ 576-5728
email: reports@adonis.osti.gov

\begin{abstract}
Available to the public from the National Technical Information Service, U.S. Department of Commerce, 5285 Port Royal Rd., Springfield, VA 22161 ph: (800) 553-6847 fax: $(703) 605-6900$ email: orders@ntis.fedworld.gov online ordering: http://www.ntis.gov/ordering.htm
\end{abstract}

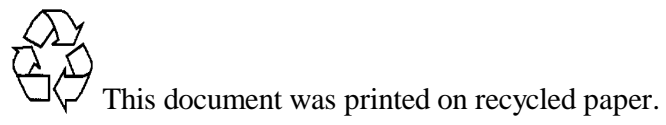




\section{Inventory of U.S.-led International Activities on Building Energy Efficiency}

\section{Initial Findings}

A Delgado

M Evans

April 2010

Prepared for the U.S. Department of Energy

under Contract DE-AC05-76RL01830

Pacific Northwest National Laboratory

Richland, Washington 99352 



\begin{abstract}
Several U.S. Government agencies promote energy efficiency in buildings internationally. The types and scope of activities vary by agency. Those with the largest role include the U.S. Agency for International Development (USAID), the U.S. Department of State and the Environmental Protection Agency (EPA). Both USAID and the Department of State have a substantial presence overseas, which may present some complementarities with the Department of Energy's efforts to reach out to other countries. Generally speaking, USAID focuses on capacity building and policy issues; the Department of State focuses on broad diplomatic efforts and some targeted grants in support of these efforts, and EPA has more targeted roles linked to ENERGY STAR appliances and a few other activities. Several additional agencies are also involved in trade-related efforts to promote energy efficiency in buildings. These include the Department of Commerce, the ExportImport Bank, the Overseas Private Investment Corporation and the Trade and Development Agency (TDA). This initial synthesis report is designed to summarize broad trends and activities relating to international cooperation on energy efficiency in buildings, which can help the U.S. Department of Energy (DOE) in developing its own strategy in this area. The Pacific Northwest National Laboratory will develop a more complete synthesis report later in 2010 as it populates a database on international projects on building energy efficiency.
\end{abstract}

\title{
Introduction
}

The Office of Energy Efficiency and Renewable Energy (EERE) and the Buildings Technology Program (BTP) seek to provide a strategic contribution in support of DOE and the U.S. Government's efforts to establish the U.S. as a leading producer and supplier of clean energy technologies and services abroad, including in the buildings sector. In line with this objective, PNNL developed an inventory examining the roles and activities of other organizations working on energy efficiency in buildings internationally. The inventory represents a tool by which EERE and BTP managers could identify synergies, opportunities for collaboration and potential areas of duplication.

To date, U.S. government agencies covered in the inventory include USAID, the U.S. Department of State, the U.S. Department of Commerce, EPA, Export-Import Bank of the United States, Overseas Private Investment Corporation, TDA, NASA, Peace Corps, and the U.S. Army Corps of Engineers. World Bank projects on building energy efficiency have also been included. Other U.S.-supported development banks and intergovernmental organizations will be included at a future date. There are also plans to transform the inventory into a dynamic, searchable, web-based database.

Information contained in the inventory is primarily based on project updates, official press releases and online project databases. Interviews with program leaders have not been conducted at this stage. As a result, the inventory is not an exhaustive list, but represents the major activities to the best of our knowledge.

\section{Initial Findings}

The agencies with the largest presence overseas working on building energy efficiency are USAID and the Department of State. Although EPA does not many staff overseas, it does have several international activities related to buildings, including its ENERGY STAR. 
At USAID, the various international activities focus on technical assistance. They are managed under several bureaus within the agency. USAID is broken up into geographic bureaus, responsible for the overall activities in countries where programs exist, and three functional bureaus, which conduct agency programs that are internationally-oriented or which span geographic boundaries. The functional bureaus are broad in scope: 1) Global Health, 2) Economic Growth, Agriculture and Trade, and 3) Democracy, Conflict, and Humanitarian Assistance. Each geographic bureau is comprised of Overseas Missions. ${ }^{1}$ USAID establishes a field Mission when it has one or more continuing programs. These programs range from minor ones that have a single focus to major programs with multiple types of assistance within sectors. USAID has Missions in the majority of developing and transition countries.

The Asia and Europe \& Eurasia Bureaus have the most activities pertaining to energy efficiency in buildings, with several activities occurring in the China and India Missions, and the Serbian and Ukrainian Missions, respectively. In the Asian Bureau's strategy, two out of six principal activities are relevant to energy efficiency and EERE's objective to expand its international portfolio: "Promoting sound environmental conservation and energy practices" and "developing regional institutions such as ASEAN and APEC ${ }^{2}$ through multilateral cooperation." 3 The Europe \& Eurasia Bureau is actively working on three general areas: Economic Growth; Democracy, Governance and Social Transition; and Health. Compared to the Asia Bureau, the Europe \& Eurasia Bureau does not support as many energy efficiency assistance programs; still, there are a few notable projects. Such is the case with a $\$ 15$ million, three-year Municipal Heating Reform Project in Ukraine, ${ }^{4}$ which is addressing the country's low energy efficient heating systems by helping municipalities strengthen their legal, regulatory and institutional framework to improve heating services. Some of the activities include performing municipal energy assessments; assistance with acquiring financing for energy efficiency projects; and implementation of energy efficient technologies and methodologies in 20 cities selected for pilot projects. In the past, the Europe and Eurasia Bureau cooperated with DOE in establishing energy efficiency centers in Russia, Ukraine and several other countries in the region.

USAID building energy efficiency activities that cross geographic boundaries are found under the Economic Growth, Agriculture and Trade Bureau. Two of the most relevant programs under this Bureau are the Environment and Science Policy, and the Energy and Information Technology programs. In addition to these two programs, the functional bureau directs the Global Climate Change Program. This cross-cutting program supports missions and other bureaus by providing technical resources that can help build capacity in countries for addressing climate change, reducing greenhouse gas emissions, assessing region vulnerability to climate change impacts and providing support for U.S. foreign policy objectives regarding climate change.

\footnotetext{
${ }^{1}$ For a full list of all USAID Overseas Missions, please see http://www.usaid.gov/locations/missiondirectory.html.

${ }^{2}$ Association of Southeast Asian Nations (ASEAN) and Asia-Pacific Economic Cooperation (APEC)

${ }^{3}$ See: http://www.usaid.gov/locations/asia/

${ }^{4}$ The Municipal Heating Reform Project is being implemented by the International Resources Group who is working with the Government of Ukraine, nongovernmental organizations and numerous subcontractors, including the Alliance to Save Energy and RTI International. For more information, please see http://www.irgltd.com/Our_Work/Projects/USAID\%20Insight\%20May\%202009\%20\%282\%29.pdf
} 
Just as China and India represent the highest priorities for EERE engagement internationally, they are important partners for other U.S. agencies as well, particularly USAID. Building energy efficiency work is being conducted under the U.S.-China Sustainable Buildings Partnership, for instance, which is managed by the Regional Development Mission for Asia. This is a special mission under the Asia Bureau, which manages regional and transnational development assistance programs in Asian countries without USAID bilateral missions. The US-China Sustainable Buildings Partnership promotes demand-side energy efficiency in China's building sector by providing policymakers and the marketplace with tools and frameworks to drive large scale action. The partnership between USAID and the Indian government on building energy efficiency has been active since the signing of the Energy Conservation and Commercialization (ECO) bilateral project agreement in 2000. The present focus of the program (part of Phase III of the program) is to develop institutional capacity at the state level by working with energy development agencies and to continue efforts on developing the implementation framework for energy efficiency in buildings (new and existing) and the municipal sector.

Under the Foreign Operations Appropriations bill, the Department of State plays a major role in deciding on priorities and allocations of funding, which includes much of the funding that DOE, USAID, EPA and other agencies receive in support of international assistance programs. Similar to USAID, the Department of State has staff in numerous countries working on energy and climate change issues. Most activities relevant to building energy efficiency are under the direction of the Bureau of Oceans and International Environmental and Scientific Affairs, which is overseen by the Office of the Under Secretary for Democracy and Global Affairs. ${ }^{5}$ Under this Bureau, several activities are taking place under various, broad energy-related initiatives, including the U.S. Asia-Pacific Partnership on Clean Development and Climate (APP) Program Office, the Major Economies Forum on Energy and Climate, and bilateral climate and energy partnerships with Canada and Mexico.

Similar, but fewer, active efforts are captured under the regional bureaus in the Office of the Under Secretary for Political Affairs. For example, the Bureau of Western Hemisphere Affairs is overseeing activities under the Energy and Climate Partnership of the Americas, ${ }^{6}$ a partnership in which more than one U.S. agency is participating in, including DOE. One Department of State activity under this partnership, for example, is supporting Peace Corps volunteers in addressing energy poverty using small grants and local training to build the capacity of rural communities. Through this initiative, volunteers are introducing energy efficient practices and alternative energy technologies such as small scale solar panels and cook stoves.

The Department of State admittedly acknowledges that, in the past decade, security concerns have taken priority over energy and sustainability in managing its more than 280 U.S. embassies and consulates. ${ }^{7}$ In the last five years, however, there have been a number of initiatives made by the Department of State's Bureau of Overseas Buildings Operations in making the embassies and

\footnotetext{
${ }^{5}$ An organizational diagram of the State Department is available at http://www.state.gov/documents/organization/99588.pdf.

${ }^{6}$ The Energy and Climate Partnership of the Americas is an intergovernmental partnership which was initiated after the April 2009 Summit of the Americas in Port of Spain, Trinidad and Tobago. The partnership is comprised of initiatives that focus on energy efficiency, renewable energy, cleaner fossil fuels, energy poverty, and climate change, and infrastructure. For more information, please see http://ecpamericas.org/about.php?lan=e

${ }^{7}$ See: http://www.state.gov/documents/organization/128748.pdf
} 
consulates more energy efficient. The Bureau of Overseas Buildings Operations counts on assistance from DOE's Federal Energy Management Program (FEMP) in developing and managing the Department of State's own large-scale energy management improvement efforts in its overseas facilities. These efforts include cooperation with the League of Green Embassies, as well as the Bureau's Green Team and LEED standards for all new construction as established under a Memorandum of Understanding ${ }^{8}$ between the Bureau of Overseas Buildings Operations and FEMP.

Following such energy mandates as the Energy Policy Act 2005, the 2006 Federal Leadership in High Performance and Sustainable Buildings Memorandum of Understanding; the 2007 Executive Order: Strengthening Federal Environmental, Energy, and Transportation Management; and the Energy Independence and Security Act (EISA) 2007; the Bureau of Overseas Buildings Operations formed a Green Team made up of technical experts in the fields of real-estate, planning, architecture, civil engineering, electrical engineering, mechanical engineering, interiors, security, construction and commissioning. The team of experts is dedicated to supporting the Bureau "as a leader in high performance and sustainable buildings by incorporating principals of sustainable design and energy efficiency into all building projects."9 To date, the team has prepared technical studies and energy conservation measures, implemented Green Building Certification, ${ }^{10}$ and written a Green Guide for Embassy and Consulate Operations, which outlines best practice strategies for increasing efficiency, reducing consumption and promoting the government's commitment to conservation in its operations. As a result of these efforts, for example, solar panels have been placed in many U.S. embassies, including those in Geneva; Abuja, Nigeria; and Kigali, Rwanda.

Initiated by the U.S. Ambassador to Sweden, a handful of U.S. embassies and consulates in Europe also formed a League of Green U.S. Embassies in 2007, which act collectively to obtain funding for a number of environmental initiatives. For example, Embassies are replacing all of their incandescent lighting with compact fluorescent lights, installing motion sensors and implementing automatic shut-off for computers. The League has now more than 30 participating embassies that extend beyond Europe to include Abu Dhabi and Kathmandu. The League partners with the Bureau of Overseas Buildings Operations and shares the Bureau's best practices on energy conservation, using public affairs to highlight these practices. Recently in 2009, the Greening Diplomacy Initiative was also introduced by the Secretary of State as a pledge to improve the environmental impact of U.S. operations. A year after the Initiative's inception, the D.C. Forum for Greening Embassies was launched to bring foreign missions together to exchange ideas on environmental issues and operational practices.

Perhaps more importantly, however, U.S. Embassies represent an opportunity for DOE to share information with countries that it may not have the ability to collaborate with extensively. U.S. Embassies have staff overseas who meet regularly with other governments. Most embassies have

\footnotetext{
${ }^{8}$ See: http://www.energy.gov/media/FEMP-State_MOU.pdf

${ }^{9}$ See: http://www.state.gov/documents/organization/128748.pdf

${ }^{10}$ Currently, there are three LEED-certified embassies: Panama City; Sofia, Bulgaria; and Johannesburg. Retrofitting existing structures has been a challenge for the Bureau as security issues have to be considered and retaining the character of the many historical buildings used as embassies is also a concern. For new, major building projects, such as the future U.S. embassy in Senegal, the Bureau of Overseas Building Operations is aiming for LEED certification.
} 
staff with knowledge of energy issues, although they have fairly broad portfolios and may not have detailed expertise on energy efficiency policy. EERE and BTP do not have the local presence, but they do have extensive information available on a range of energy efficiency policies and technologies.

For EPA, most work pertaining to international building energy efficiency is found within the Office of Atmospheric Programs under the Office of Air and Radiation. Like USAID, EPA oversees numerous programs designated under the management of the appropriate Office. The Office of Atmospheric Programs oversees such programs as eeBuildings and ENERGY STAR. eeBuildings is one of three international programs managed by the Climate Change Division within this Office. The program forms partnerships with multinational corporations, local businesses, NGOs and government agencies that share eeBuildings' goal to help building owners, managers and tenants enhance the energy efficiency of buildings worldwide. The program works on a voluntary, no-cost approach-basis and activities have been thus far implemented in Brazil, China, India and the Philippines. Agreements to promote ENERGY STAR-qualified products $^{11}$ were also instituted with government agencies abroad. The partnerships were established to unify voluntary energy-efficiency labeling programs in major global markets and to facilitate participation in the programs by providing a single set of qualifications, as opposed to a diverse set of country-specific requirements. Just as ENERGY STAR computers and monitors were the first labeled products when ENERGY STAR was established in 1992, so is this true now for most international partnering countries that implement ENERGY STAR labels. A few countries have expanded their labels to include more than office equipment, such as home electronics. Canada, more notably, also implements ENERGY STAR for heating and cooling equipment, home appliances, lighting and signage, distribution transformers, commercial solid door refrigerators and freezers, and windows.

Other international energy efficiency activities are taking place in the Office of Regional and Bilateral Affairs within the Office of International and Tribal Affairs. Such is the case with the Clean Air and Energy projects in China. For example, EPA is providing technical support to the Government of China to build capacity to implement and develop labels under a voluntary energy efficiency labeling program much like ENERGY STAR. Specifications for more than 25 products have been developed, such as air-conditioners and televisions. Under the same program, EPA is also supporting the Collaborative Labeling and Appliance Standards Program (CLASP) who are providing technical expertise to Chinese partners in designing and implementing minimum energy performance standards and mandatory information labels for appliances and equipment. In the past, EPA also supported the development of building energy codes in Russia, Kazakhstan and other countries.

\section{Relevance for EERE Strategy Setting}

The strengths and assets of EERE and other agencies are in many ways complementary, even if there are also some areas of potential overlap. EERE and BTP have limited presence in other countries because their staff are primarily based in Washington, DC. This can limit ongoing contact and engagement with international officials, particularly outside of the largest countries. Collaboration with internationally-oriented agencies and bodies such as the Department of State

\footnotetext{
${ }^{11}$ EPA works internationally under ENERGY STAR only on appliances, not on ENERGY STAR homes and buildings.
} 
and the World Bank represents one vehicle by which DOE can expand its reach. Although international agencies engage extensively with policymakers, companies and other stakeholders around the world, they may have only a superficial knowledge of building energy efficiency policy and its potential role and its benefits. For example, the Department of State has staff in almost every country working on energy and economic issues, and better understanding of the role of energy efficiency policy could have a positive impact on these diplomatic engagements. In addition, understanding the priorities of other agencies can help improve coordination, reduce duplication and increase impact of the Administration's work.

EERE and BTP have several unique strengths that they can bring to international collaboration. They and their laboratory partners have extensive technical expertise, not just on technologies but also on practical programs. Most of EERE's expertise is directed at domestic programs, but with some relatively minor modifications, many of the concepts are also relevant for other countries. Some examples include building energy codes, FEMP, appliance standards, and voluntary approaches to collaborating with large commercial building operators.

National laboratories often have excellent in-country contacts that multiple agencies can benefit from. This can be observed with the national energy efficiency centers, with CLASP, and with collaboration between national laboratories such as the Lawrence Berkeley National Laboratory (LBNL) and experts in China, for example.

Inherently, there will likely be some challenges in defining roles in collaborating on deployment issues, because deployment-type activities are in the core competencies of USAID and EPA as well. Exploring opportunities where DOE has a strategic advantage, such as with R\&D, knowledge of successful domestic policies and related tools, and established relationships through the national laboratories, will likely help in identifying areas where the benefits of collaboration outweigh some of these challenges.

Looking forward in this project, the interview process that will further develop the inventory of international building energy efficiency activities will be particularly helpful for DOE in learning where work is headed in other U.S. agencies and in having full, easy access to information on activities within DOE. As the inventory becomes a dynamic database that enables user updates, it will further become an instrumental tool in guiding EERE and BTP managers to identify priorities of other agencies, U.S.-supported development banks, intergovernmental organizations, and eventually, foundations and non-governmental organizations. 